\title{
Characteristics and thermodynamics of the interaction of 6-shogaol with human serum albumin as studied by isothermal titration calorimetry
}

\author{
Shevin Rizal Feroz, Sri Nurestri Abdul Malek, Saad Tayyab* \\ Biomolecular Research Group, Biochemistry Program, Institute of Biological Sciences, Faculty of Science, University of \\ Malaya, Kuala Lumpur, Malaysia
}

\begin{abstract}
The interaction between 6-shogaol, a pharmacologically active ginger constituent, and human serum albumin (HSA), the main in vivo drug transporter, was investigated using isothermal titration calorimetry (ITC). The value of the binding constant, $K_{a}\left(5.02 \pm 1.37 \times 10^{4} \mathrm{M}^{-1}\right)$ obtained for the 6-shogaol-HSA system suggested intermediate affinity. Analysis of the ITC data revealed feasibility of the binding reaction due to favorable enthalpy and entropy changes. The values of the thermodynamic parameters suggested involvement of van der Waals forces, hydrogen bonds and hydrophobic interactions in the 6-shogaol-HSA complex formation.
\end{abstract}

Uniterms: 6-Shogaol. Human serum albumin/Isothermal titration calorimetry. Ligand-protein interaction.

\section{INTRODUCTION}

Natural products and their bioactive constituents are increasingly recognized as sources for the discovery of new drugs and the treatment of diseases. The rhizome of Zingiber officinale (common ginger) is a particularly rich source of bioactive phytochemicals of different classes; it is thus a major target for discovering new phytomedicines (Bode, Dong, 2011). One of the pharmacologically significant compounds that is abundantly present in this rhizome is 6-shogaol, whose structure is shown in Figure 1. Its therapeutic properties have been extensively studied and it is well established that 6-shogaol possesses significant anticancer, antioxidant and anti-inflammatory potential (Chen et al., 2012; Chrubasik, Pittler, Roufogalis, 2005; Ha et al., 2012).

The efficacy of biologically active compounds as pharmaceutical agents depends mainly upon their interactions with proteins in the circulatory system. Human serum albumin (HSA) is the most abundant serum protein in the body and serves as the major carrier protein

\footnotetext{
*Correspondence: S. Tayyab . Institute of Biological Sciences. Faculty of Science, University of Malaya, 50603 Kuala Lumpur, Malaysia. E-mail: saadtayyab2004@yahoo.com
}

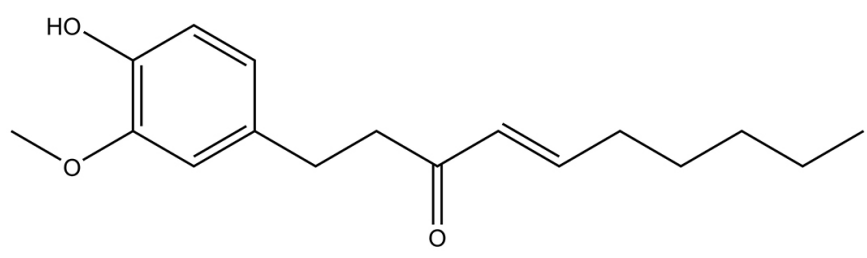

FIGURE 1 - Chemical structure of 6-shogaol.

for a wide variety of molecules, including drugs and metabolites (Peters, 1996). Therefore, it plays a dominant role in drug disposition, affecting the biodistribution, metabolism and elimination of the molecules to which it binds (Peters, 1996). Hence, characterization of ligandprotein interactions is vital in order to determine the pharmacokinetic profiles of these compounds and to assess their therapeutic potential.

Isothermal titration calorimetry (ITC) has emerged as a widely used biophysical tool to monitor binding reactions and to evaluate the thermodynamic parameters involved in such processes (Bou-Abdallah, Terpstra, 2012). This technique directly measures the heat changes associated with a reaction and allows for a complete characterization of the energetics of a system (Leavitt, Freire, 2001). Although other methods are also able to provide information about the binding affinity of ligandprotein interactions, only ITC is capable of measuring in 
a single experiment the thermodynamic terms that define the binding affinity (Leavitt, Freire, 2001).

In view of the advantages offered by ITC for studying binding reactions involving biomolecules, we present the binding properties of 6-shogaol to HSA, including quantification of the thermodynamics governing this interaction, as obtained from ITC data.

\section{MATERIALS AND METHODS}

\section{Materials}

Defatted human serum albumin (HSA) (Lot \#068K7538V) was acquired from Sigma-Aldrich Co. (St. Louis, MO, USA), and 6-shogaol was isolated from the rhizomes of Zingiber officinale var. officinale, following standard procedures (Jolad et al., 2004, 2005; Kim et al., 2008 ). The purity of the compound was $>95 \%$ based on nuclear magnetic resonance (NMR) analysis. All other chemicals used were of analytical grade purity.

\section{Analytical procedures}

HSA stock solution $(30 \mu \mathrm{M})$ was prepared in $10 \mathrm{mM}$ sodium phosphate buffer, $\mathrm{pH} 7.4$, and its concentration was determined spectrophotometrically using $E_{1 \mathrm{~cm}}^{1 \%}$ of 5.3 at $280 \mathrm{~nm}$ (Wallevik, 1973). Absorbance measurements were made on a Shimadzu UV-2450 double beam spectrophotometer (Shimadzu Corp., Kyoto, Japan) using quartz cuvettes with a $1 \mathrm{~cm}$ path length. The stock solution of 6-shogaol $\left(10 \mathrm{mg} \mathrm{mL}^{-1}\right)$ was prepared by dissolution in absolute ethanol.

\section{Isothermal titration calorimetry}

ITC experiments were performed on a Nano ITC microcalorimeter (TA Instruments, New Castle, DE, USA) at $25^{\circ} \mathrm{C}$. The titrant (6-shogaol) and protein solutions were prepared in the same buffer $(10 \mathrm{mM}$ sodium phosphate buffer, $\mathrm{pH}$ 7.4) and degassed under vacuum for $20 \mathrm{~min}$ prior to the titration experiments. After loading the sample and reference cells with HSA $(25 \mu \mathrm{M})$ and buffer alone, respectively, a syringe $(250 \mu \mathrm{L})$ containing 6 -shogaol (380 $\mu \mathrm{M})$ was placed into the microcalorimeter. The titration experiment involved 25 consecutive injections of $10 \mu \mathrm{L}$ of titrant added intermittently every $400 \mathrm{~s}$, with a stirring speed of $250 \mathrm{rpm}$ to ensure homogeneous mixing of the solutions. Appropriate blank experiments involving injections of the ligand into the buffer solution were also performed under similar conditions for correcting the heat of the dilution and the mixing of the solutions.
Both the HSA and the buffer solutions contained the same concentration of ethanol $(2.5 \%)$ as in the 6-shogaol solution, in order to nullify the effect of heat generation due to solvent dilution.

The amount of heat, $Q$, liberated with each injection was calculated by integrating the heat-rate peaks using NanoAnalyze 2.4.1 software (TA Instruments, New Castle, DE, USA). The corrected calorimetric data were analyzed based on an independent binding model to determine the values of the association constant $\left(K_{a}\right)$ and binding stoichiometry $(n)$, as well as the enthalpy and entropy changes $(\Delta H$ and $\Delta S)$ of the reaction. The value of the freeenergy change $(\Delta G)$ was subsequently calculated with the help of the following equation:

$$
\Delta G=\Delta H-T \Delta S
$$

The experiments were performed in four replicates, and the results are presented as the average \pm standard deviation of the three best replicates.

\section{RESULTS AND DISCUSSION}

ITC experiments were carried out to determine the binding characteristics and the thermodynamics of the interaction between 6-shogaol and HSA. Figure 2A shows the ITC thermogram at $25^{\circ} \mathrm{C}$, depicting the calorimetric response upon the binding of 6-shogaol to HSA. As can be seen in the figure, the negative peaks resulting from the reaction suggested the exothermic nature of the binding process. Integration of the heat rates into the total heat released $(Q)$ per mol of titrant was plotted against the ligand/protein molar ratio, shown in Figure 2B. Analysis of the binding isotherm using an independent binding model yielded the values of the binding and thermodynamic parameters (Table I).

The $K_{a}$ value obtained for the 6-shogaol-HSA system $\left(5.02 \times 10^{4} \mathrm{M}^{-1}\right)$ was found to be in the range of $1-15 \times 10^{4} \mathrm{M}^{-1}$, which is shown for a number of other ligand-protein complexes (Dufour, Dangles, 2005), indicating intermediate affinity between 6-shogaol and HSA. This value of $K_{a}$ is desirable for the transportation of the ligand in circulation, as well as its release at the target site. On the other hand, the binding stoichiometry of the reaction, $n$, was found to be 1.31 . The positive sign for the $\Delta S$ value and the negative sign for the $\Delta H$ value showed that the binding process was both entropically and enthalpically favorable at $25^{\circ} \mathrm{C}$ and contributed significantly to the thermodynamic feasibility of the reaction, as evident from the negative sign for the $\Delta G$ value (Table I). 
TABLE I - Binding and thermodynamic parameters of the interaction between 6-shogaol and HSA derived from ITC measurements at $\mathrm{pH} 7.4$ and $25^{\circ} \mathrm{C}$

\begin{tabular}{ccccc}
\hline $\begin{array}{c}K_{a} \\
\left(\mathrm{M}^{-1}\right)\end{array}$ & $n$ & $\begin{array}{c}\Delta H \\
\left(\mathrm{~kJ} \mathrm{~mol}^{-1}\right)\end{array}$ & $\begin{array}{c}\Delta S \\
\left(\mathrm{~J} \mathrm{~mol}^{-1} \mathrm{~K}^{-1}\right)\end{array}$ & $\begin{array}{c}\Delta G \\
\left(\mathrm{~kJ} \mathrm{~mol}^{-1}\right)\end{array}$ \\
\hline$(5.02 \pm 1.37) \times 10^{4}$ & $1.31 \pm 0.14$ & $-20.39 \pm 4.06$ & $21.41 \pm 4.64$ & $-26.77 \pm 5.44$ \\
\hline
\end{tabular}

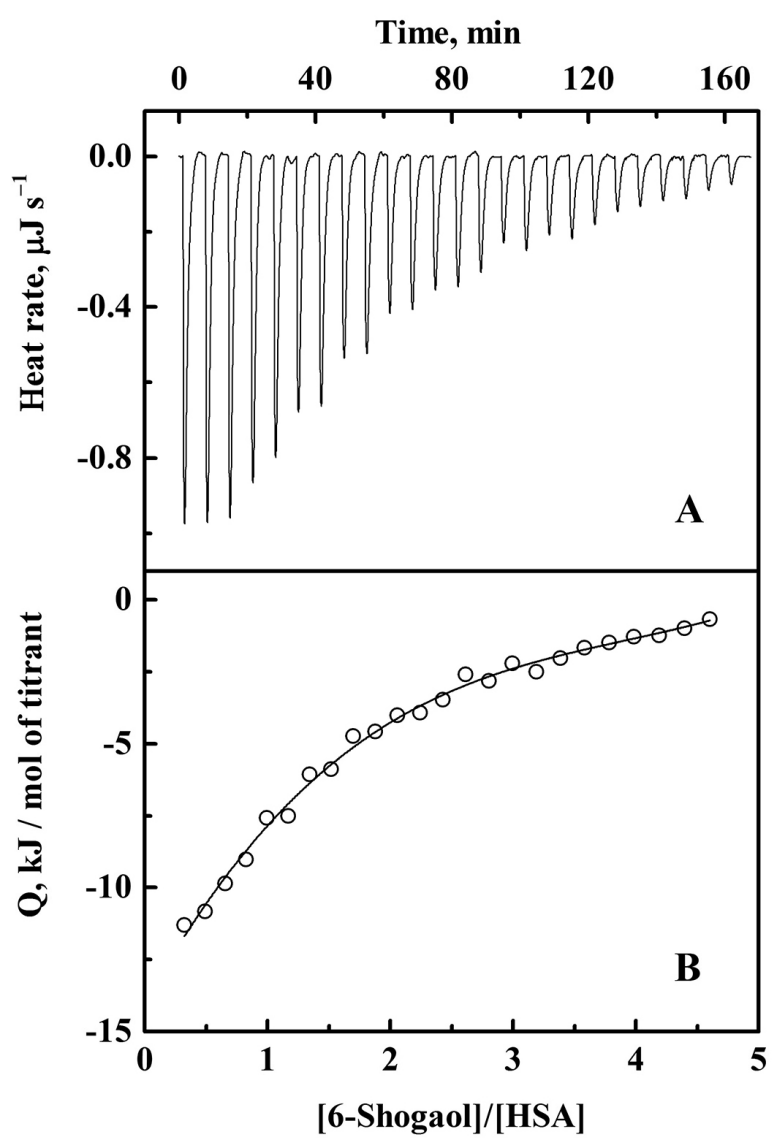

FIGURE 2 - (A) Calorimetric response to successive injections of 6-shogaol $(380 \mu \mathrm{M})$ into HSA $(25 \mu \mathrm{M})$. (B) Integrated plot of the amount of heat liberated $(Q)$ per injection as a function of the 6-shogaol/HSA molar ratio.

The values of these thermodynamic parameters can shed light on the intermolecular forces involved in the interaction between 6-shogaol and HSA. The observed entropic gain may be ascribed to the disruption of water layers originally surrounding the ligand and protein molecules, due to the involvement of hydrophobic interactions in the complex formation (Ross, Subramanian, 1981). Since the formation of hydrogen bonds and van der Waals forces frequently result in heat evolution (Ross, Subramanian, 1981), a negative value for $\Delta H$ also points to the involvement of these forces in the 6-shogaol-HSA interaction. It is interesting to note that the binding reaction is enthalpy-dominated under the experimental conditions used, suggesting that hydrogen bonding in particular is the major force involved in the complexation between 6-shogaol and HSA. The participation of these intermolecular forces in the binding of 6-shogaol to HSA is well-supported by the structural features of 6-shogaol, which possesses both apolar and polar characteristics (Figure 1). As suggested in earlier reports (Caruso et al., 2014; Feroz et al., 2012, 2013; Molina-Bolivar et al., 2014; Neamtu, Tosa, Bogdan, 2013), it is not possible to account for the observed thermodynamic parameters according to a single intermolecular-force model. Therefore, the energetics data obtained in this study seem to reflect the collective contributions of hydrophobic interactions, van der Waals forces and hydrogen bonds in 6-shogaol-HSA complexation.

\section{CONCLUSION}

In summary, the present study elucidates the binding properties and thermodynamic quantities of the interaction between 6-shogaol and HSA. The calorimetric data suggested that the binding is of intermediate affinity and is mediated by van der Waals forces, hydrogen bonds and hydrophobic interactions. These results can be helpful in understanding chemico-biological interactions in drug design.

\section{ACKNOWLEDGEMENTS}

This work was financially supported by the University of Malaya via the Postgraduate Research Fund (PG073/2013B) to S.R.F. We thank the dean of the Faculty of Science and the head of the Institute of Biological Sciences at the University of Malaya for providing the necessary facilities.

\section{REFERENCES}

BODE, A.M.; DONG, Z. The amazing and mighty ginger. In: BENZIE, I.F.F.; WACHTEL-GALOR, S. (Ed.). Herbal medicine: Biomolecular and clinical aspects. Boca Raton: CRC Press, 2011. p.131-156. 
BOU-ABDALLAH, F.; TERPSTRA, T.R. The thermodynamic and binding properties of the transferrins as studied by isothermal titration calorimetry. Biochim. Biophys. Acta, v.1820, n.3, p.318-325, 2012.

CARUSO, I.P.; VILEGAS, W.; DE SOUZA, F.P.; FOSSEY, M.A.; CORNELIO, M.L. Binding of antioxidant flavone isovitexin to human serum albumin investigated by experimental and computational assays. J. Pharm. Biomed., v.98, p.100-106, 2014.

CHEN, H.; LV, L.; SOROKA, D.; WARIN, R.F.; PARKS, T.A.; HU, Y.; ZHU, Y.; CHEN, X.; SANG, S. Metabolism of [6]-shogaol in mice and in cancer cells. Drug Metab. Dispos., v.40, n.4, p.742-753, 2012.

CHRUBASIK, S.; PITTLER, M.H.; ROUFOGALIS, B.D. Zingiberis rhizoma: A comprehensive review on the ginger effect and efficacy profiles. Phytomedicine, v.12, n.9, p.684701,2005

DUFOUR, C.; DANGLES, O. Flavonoid-serum albumin complexation: Determination of binding constants and binding sites by fluorescence spectroscopy. Biochim. Biophys. Acta, v.1721, n.1-3, p.164-173, 2005.

FEROZ, S.R.; MOHAMAD, S.B.; BUJANG, N.; MALEK, S.N.A.; TAYYAB, S. Multispectroscopic and molecular modeling approach to investigate the interaction of flavokawain B with human serum albumin. J. Agr. Food Chem., v.60, n.23, p.5899-5908, 2012.

FEROZ, S.R.; MOHAMAD, S.B.; BAKRI, Z.S.D.; MALEK, S.N.A.; TAYYAB, S. Probing the interaction of a therapeutic flavonoid, pinostrobin with human serum albumin: Multiple spectroscopic and molecular modeling investigations. PLoS ONE, v.8, n.10, e76067, 2013.

HA, S.K.; MOON, E.; JU, M.S.; KIM, D.H.; RYU, J.H.; OH, M.S.; KIM, S.Y. 6-Shogaol, a ginger product, modulates neuroinflammation: A new approach to neuroprotection. Neuropharmacology, v.63, n.2, p.211-223, 2012.

JOLAD, S.D.; LANTZ, R.C.; SOLYOM, A.M.; CHEN, G.J.; BATES, R.B.; TIMMERMAN, B.N. Fresh organically grown ginger (Zingiber officinale): Composition and effects on LPS-induced $\mathrm{PGE}_{2}$ production. Phytochemistry., v.65, n.13, p.1937-1954, 2004.
JOLAD, S.D.; LANTZ, R.C.; CHEN, G.J.; BATES, R.B.; TIMMERMAN, B.N. Commercially processed dry ginger (Zingiber officinale): Composition and effects on LPSstimulated $\mathrm{PGE}_{2}$ production. Phytochemistry, v.66, n.13, p.1614-1635, 2005 .

KIM, J.S.; LEE, S.I.; PARK, H.W.; YANG, J.H.; SHIN, T.Y.; KIM, Y.C.; BAEK, N.I.; KIM, S.H.; CHOI, S.U.; KWON, B.M.; LEEM, K.H.; JUNG, M.Y.; KIM, D.K. Cytotoxic components from the dried rhizomes of Zingiber officinale Roscoe. Arch. Pharm. Res., v.31, n.4, p.415-418, 2008.

LEAVITT, E.; FREIRE, E. Direct measurement of protein binding energetics by isothermal titration calorimetry. Curr. Opin. Struc. Biol., v.11, n.5, p.560-566, 2001.

MOLINA-BOLIVAR, J.A.; GALISTEO-GONZALEZ, F.; CARNERO RUIZ, C.; MEDINA-O’ DONNELL, M.; PARRA, A. Spectroscopic investigation on the interaction of maslinic acid with bovine serum albumin. J. Lumin., v.156, p.141-149, 2014

NEAMTU, S.; TOSA, N.; BOGDAN, M. Spectroscopic investigation of tolmetin interaction with human serum albumin. J. Pharm. Biomed., v.85, p.277-282, 2013.

PETERS, T.Jr. All about albumin: Biochemistry, genetics and medical applications. San Diego:Academic Press, 1996.432p.

ROSS, P.D.; SUBRAMANIAN, S. Thermodynamics of protein association reactions: Forces contributing to stability. Biochemistry, v.20, p.3096-3102, 1981.

WALLEVIK, K. Reversible denaturation of human serum albumin by $\mathrm{pH}$, temperature, and guanidine hydrochloride followed by optical rotation. J. Biol. Chem., v.248, n.8, p.2650-2655, 1973.

Received for publication on $27^{\text {th }}$ July 2015 Accepted for publication on $03^{\text {rd }}$ June 2016 